\title{
Detection of Brucella canis in blood, urine and seminal fluid of a naturally infected dog by PCR
}

\author{
Detecção de Brucella canis no sangue, urina e sêmen de cão \\ naturalmente infectado através de PCR
}

\author{
Fabiana S. Volkweis' , Lilian Cristina G. Cavalcanti² , Hélio Blume ${ }^{3}$, Helvécio L. Santos Júnior ${ }^{3}$, Andrea M. Lazzari \& \\ Fernanda Mulinari ${ }^{4 *}$ \\ 'Veterinary, Master in Science and Animal Health. União Pioneira de Integração Social - UPIS, Planaltina, Brasília, DF, Brasil \\ 2Zootecnista. União Pioneira de Integração Social - UPIS, Planaltina, Brasília, DF, Brasil \\ ${ }^{3}$ Veterinary, PhD, Teacher. Departamento de Medicina Veterinária, Faculdades Integradas, União Pioneira de Integração Social \\ - UPIS, Planaltina, Brasília, Brasil \\ ${ }^{4}$ Pharmaceuticals, PhD, Teacher. Departamento de Medicina Veterinária, Laboratório de Biologia Molecular, União Pioneira de \\ Integração Social - UPIS, Planaltina, Brasília, DF. Brasil
}

\begin{abstract}
Canine Brucellosis is a bacterial infectious disease that affects dogs around the world. The laboratory diagnosis is based on direct and indirect methods and should be performed when there is evidence from clinical and epidemiological signs. In this study, we observed scrotal dermatitis recurrent and resistant to treatment in six years dog, Golden Retriever. An AGID serological test for brucellosis was positive. However, serological tests may show unspecific reactions and false positive results. Blood culture is indicated as a confirmatory test. The result of the culture was negative in all materials tested (blood cultures, urine culture and semen in tryptose broth and blood agar). Thus, the blood, urine and semen samples were tested by PCR and all samples tested were positive. After castration, the histologic evaluation showed inflammatory infiltrate in the epididymis. Vacuolar degeneration of the germinal epithelium of the seminiferous tubules was observed in the testicular parenchyma without testicular atrophy. Morphological semen evaluation showed sperm abnormalities as strongly folded tail, loose heads, curly tails, head-head, corroborating the diagnosis of brucellosis. PCR was crucial to the canine brucellosis final diagnosis, demonstrating the high sensitivity and efficiency of this test, suggesting that PCR should be included as a confirmatory test, aimed at preventing the spread of this important zoonosis.
\end{abstract}

Keywords: canine brucellosis, reaction polymerase chain, blood culture, AGID.

\section{Resumo}

A brucelose canina é uma doença bacteriana, infectocontagiosa que acomete cães de todo o mundo. O diagnóstico laboratorial é baseado em métodos diretos e indiretos e deve ser realizado quando há evidências de sinais clínicos e epidemiológicos. Neste estudo, observou-se dermatite escrotal recorrente e resistente a tratamento em cão de 6 anos, da raça Golden Retriever. Realizou-se teste sorológico IDGA para brucelose, que foi positivo. Porém, os testes sorológicos podem apresentar reações inespecíficas e resultados falsos positivos. Como teste confirmatório é indicado o exame da hemocultura. Realizou-se hemocultura, cultura de urina e sêmen em caldo triptose eágar sangue. Em todos os materiais o resultado da cultura foi negativo. Desta forma, foram testadas amostras de sangue, urina e sêmen, bem como amostras enriquecidas em caldo triptose, seguidas de PCR, que apresentaram positividade em todas as amostras testadas. O animal foi castrado e na avaliação histológica, os testículos apresentaram infiltrado inflamatório em epidídimo. No parênquima testicular observou-se degeneração vacuolar do epitélio germinativo de túbulos seminíferos, sem atrofia testicular. A avaliação morfológica do sêmen evidenciou anormalidades dos espermatozóides, dentre elas, cauda fortemente dobrada, cabeças soltas, caudas enroladas, cabeça-cabeça, corroborando para o diagnóstico de brucelose. A PCR foi fundamental para o diagnóstico final da brucelose canina, comprovando a alta sensibilidade e eficácia do exame, sugerindo que a PCR deve ser incluída como teste confirmatório, visando evitar a propagação desta importante zoonose.

Palavras-chave: brucelose canina, reação em cadeia da polimerase, hemocultura, IDGA.
How to cite: Volkweis F.S., Cavalcanti L.C.G., Blume H., Santos Júnior H.L., Lazzari A.M., \& Mulinari F. (2018). Detection of Brucella canis in blood, urine and seminal fluid of a naturally infected dog by PCR. Brazilian Journal of Veterinary Medicine, v40, e002718. DOI: 10.29374/2527-2179.bjvm002718

\section{Financial support: UPIS}

Conflict of interests: No conflict of interests declared concerning the publication of this article.

Received: July 13, 2017.

Accepted: November 14, 2017.

The study was carried out at União Pioneira de Integração Social - UPIS, Campus 2, Planaltina, DF, Brasil

\section{*Correspondence}

Fernanda Mulinari

Departamento de Medicina Veterinária, União Pioneira de Integração Social

Fazenda Lagoa Bonita, BR 20 Km 12, DF 335

$\mathrm{Km} 4,8$

CEP 73750-980 - Planaltina, Brasília (DF),

Brasil

E-mail: fermulinari@pq.cnpq.br
Copyright Volkweis et al. This is an Open Access article distributed under the terms of the Creative Commons Attribution Non-Commercial License which permits unrestricted non-commercial use, distribution, and reproduction in any medium provided the original work is properly cited. 


\section{Introduction}

Canine brucellosis is an infectious contagious disease of a chronic and debilitating nature that affects dogs, wild canids and humans, where the etiological agent is Brucella canis (Carmichael \& Greene, 2006). Healthy dogs usually become contaminated by natural copulation, oronasal contact and ingestion of contaminated fluids or tissues. Clinical signs range from asymptomatic to lymphadenopathy, orchitis, epididymitis, abortion and testicular atrophy (Carmichael \& Greene, 2006; Hollett, 2006) discospondylite (Anderson \& Binnington, 1983; Wanke, 2004) and eye disorders such as uveitis (Wanke, 2004; Ledbetter et al., 2009).

Since the recognition of these microorganisms, several serological tests have been developed for the purpose of rapid and accurate diagnosis. The diversity of tests and the lack of a reference protocol hamper the interpretation (Mateu-de-Antonio et al., 1994). The possibility of failures in serological results should be confirmed with a bacteriological study (Keid et al., 2004). Bacterial isolation is considered the only definitive test of the disease (Wanke, 2004). PCR has been developed to improve the identification of Brucella spp. and to contribute to the diagnosis of canine brucellosis (Bricker, 2002; Vieira, 2004; Keid et al., 2007b).

Little has been done to control canine brucellosis systematically in the country. It is known that it occurs, but it is not reported, mainly because the Mandatory Notification by the Ministry of Agriculture, Livestock and Supply is not required. In this way, the clinicians of small animals, owners of kennels and owners must have double surveillance to avoid thze spread of this disease (Minharro et al., 2005). In this era of international tourism, brucellosis has become a commonly imported disease in developing countries (Pappas et al., 2005). With a significant impact on dog breeding and public health worldwide, it generates great economic losses for breeders due to infertility and abortions, as well as the risk of zoonotic transmission to workers and owners of canines (Echeverri et al., 2009).

\section{Material and methods}

\section{Samples}

The project was previously approved by the Animal Use Ethics Commission -AUEC-UPIS (protocol-067/11).

Six $\mathrm{ml}$ of blood were collected, $2 \mathrm{ml}$ of EDTA test tube for bacterial culture, $2 \mathrm{ml}$ of blood in EDTA tube for PCR and finally $2 \mathrm{ml}$ of blood in a test tube without anticoagulant for separation of serum for performing the agar gel immunodiffusion test (AGID). Samples of semen and urine were collected for PCR tests.

\section{Bacterial isolation}

Blood samples collected in EDTA test tubes were inoculated into $12 \mathrm{ml}$ of phosphate tryptose broth (Difco) and incubated in an aerobic environment at $37^{\circ} \mathrm{C}$ over a period of 30 days. Every five days of replication was performed on Blood Tryptose Agar (Difco) plates, incubated in aerobiosis at $37^{\circ} \mathrm{C}$ for seven days. Subsequently, the isolated colonies were submitted to tests for bacterial identification based on morphological and biochemical characteristics (Alton, 1988).

Samples of semen and urine were also incubated in phosphate-tryptose broth to be seeded on blood tryptose agar plates to evaluate if there would be bacterial growth.

\section{Serological test}

The agar gel immunodiffusion test (AGID) was performed using serum obtained from blood samples collected in tubes without anticoagulant. The serological test was performed from the KIT produced by the Institute of Technology of Paraná (TECPAR), and following the instructions for use of the manufacturer.

\section{DNA Extraction and PCR}

The peripheral blood samples from the dogs were submitted to the nucleic acid extraction protocol described by Vieira (2004). Samples of semen and urine were inoculated in the tryptose broth and incubated at $37^{\circ} \mathrm{C}$ for 21 days, every 7 days for three consecutive weeks, $1 \mathrm{ml}$ was 
withdrawn and the same protocol was conducted for nucleic acids extraction from the peripheral blood. In order to ascertain the difference in results of the material which was freshly extracted (pure) from that which was withdrawn from the enrichment broth and to evaluate the difference in result from the time the material remained in the broth.

In order to perform the nucleic acid amplification, the primers designed by Vieira (2004), directed to the interstitial region (ITS) of the gene encoding the ribosomal RNA of Brucella were used. The sequence of the primers used were: ITS66: 5'ACA TAG ATC GCA GGC CAG TCA 3' and ITS279: 5' AGA TAC CGA CGC AAA CGC TAC 3', which amplify a fragment of 214 base pairs and are specific to the genus Brucella. The products of the extractions were quantified in a spectrophotometer (Nanodrop $\mathrm{ND} 1000^{\circledR}$ ) to measure the amount of purity and quality of the DNA.

The cycle used was performed in the following sequence: initial heating at $95^{\circ} \mathrm{C}$ for 2 minutes, followed by 40 cycles of $95^{\circ} \mathrm{C}$ for 30 seconds, $62^{\circ} \mathrm{C}$ for 30 seconds, $72^{\circ} \mathrm{C}$ for 30 seconds and final heating at $72^{\circ} \mathrm{C}$ for five minutes in a thermocycler (Applied biosystem ${ }^{\circledast}$ ).

Amplification product analysis was performed using a 1.0\% agarose gel electrophoresis technique containing ethidium bromide under the parameters of $160 \mathrm{~V}$ and 300mA in a horizontal vessel containing $1 \mathrm{X}$ TBE (Tris-Borate-EDTA) buffer. The gels were developed and visualized on a UV transilluminator and subsequently photo-documented focusing the presence of the specific band from EagleEye II Stratagene ${ }^{\circledast}$ equipment.

\section{Results and discussion}

According to Shin \& Charmichael (1999), clinical signs of canine brucellosis are mainly associated with the reproductive tract, in females the prominent sign is abortion, in males epididymitis, testicular atrophy and moist dermatitis may appear. The canine presented ulcerated scrotal moist dermatitis (Figure 1), resistant to several established treatments (anti-inflammatories and antibiotics). An imprint of the lesion was performed, which showed a predominance of leukocytes (toxic neutrophils 90\%, lymphocytes 1\% and monocytes 9\%). Presence of moderate amount of erythrocytes and desquamative epithelial cells. Presence of mucus and intracytoplasmic bacteria (coccoids) (in neutrophils) scattered on the slide.

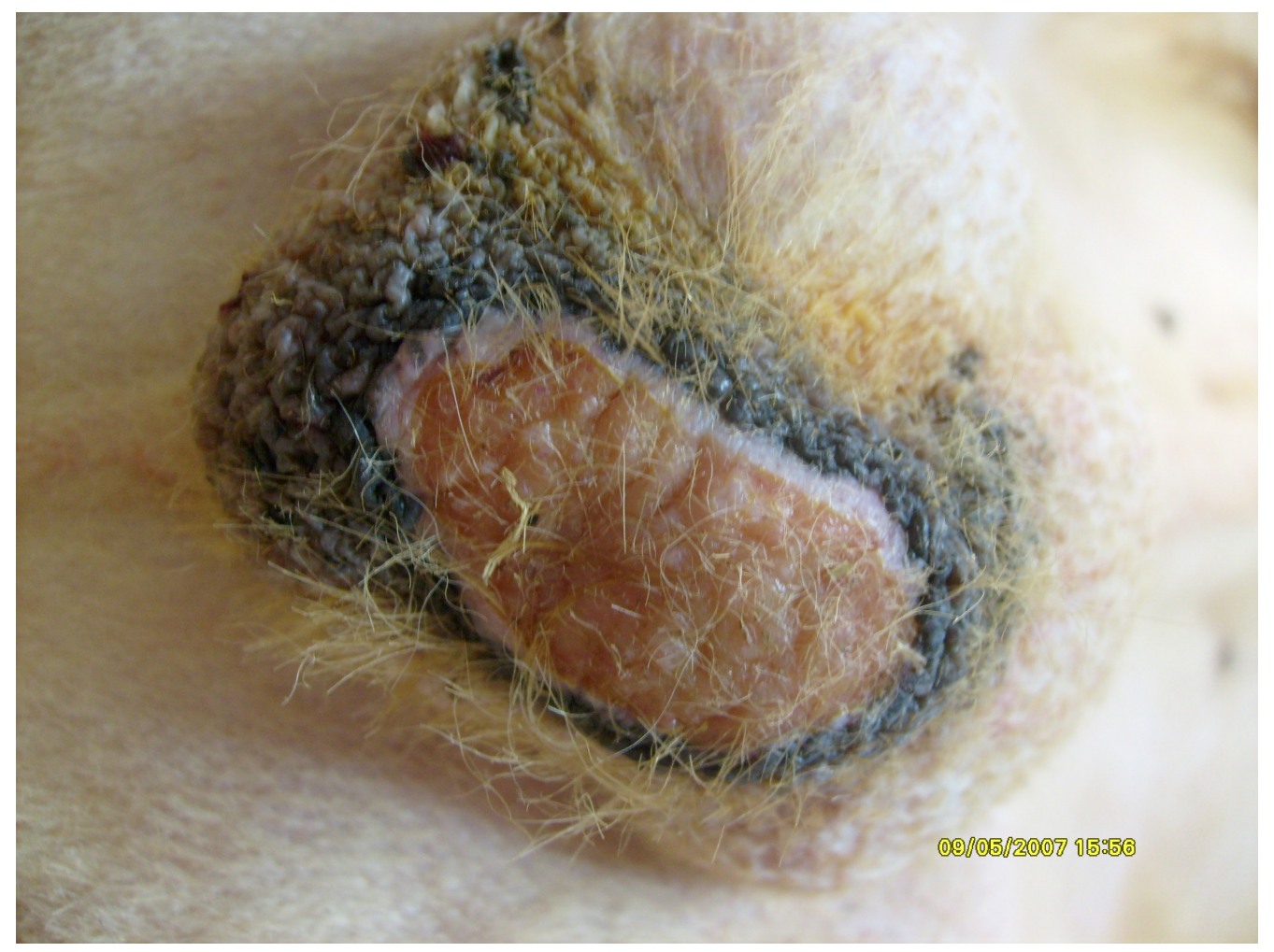

Figure 1. Canine Scrotal image with persistent ulcerated wound. 
Initially, a microbiological test was performed to identify Brucella canis bacteria for this purpose, the blood of the animal, urine and semen was first inoculated into tryptose broth and then the material was seeded in blood agar. In all materials the result of the culture was negative. This fact evidences the difficulty of the identification of the agent, since the isolation and identification of Brucella canis is a high specificity method to confirm the etiological agent of the disease, but its sensitivity may be low to the detriment of several factors, such as intermittent elimination of bacteria, poorly collected material, poorly maintained, use of antibiotics (Minharro et al., 2005). Bacteremia can be detected in blood culture for 2 to 4 weeks or even for 1 to 2 years (Carmichael \& Greene, 2006). The period and the time of the canine infection of this report cannot be affirmed as a result of a negative blood culture test.

The clinical examination of canine brucellosis is not sufficient for diagnosis and a negative blood culture cannot rule out the disease (Escobar et al., 2010). Thus, a serological test was performed. The IDGA test was positive and retested three times, and all tests had the same result. In the IDGA test, antibodies can be detected from 5 to 10 weeks post infection and persist for years. Thus, the positive serological test in the blood culture of negative animals is explained by the infection's natural evolution and persistence of the antibodies or by a possible nonspecific reaction of the immunodiffusion test, rendering the interpretation of these cases ambiguous (Carmichael \& Greene, 2006). Currently, molecular methods are being employed to test these hypotheses and to compare the sensitivity and specificity of available detection methods (Keid et al., 2007b; Noosud et al., 2009; Aras \& Uçan, 2010).

A new blood sample was collected after the positive serological result, to perform a complete blood count, total proteins and fractions, pre-surgical renal and hepatic biochemistry. Biochemical parameters were within normal range. The erythrocyte values were within normal range and the leukocytes with relative neutropenia, relative and absolute eosinophilia, relative and absolute monocytes, the presence of hyperactive and vacuolated monocytes. In a study by Megid et al. (2010) where hematological parameters of 12 dogs with brucellosis were measured, there were no significant alterations. In some cases, monocytosis was observed, corroborating with the hematological examination of the present report.

The total proteins $(7.0 \mathrm{~g} / \mathrm{dL}$ ) were within the normal range; however, observing its fractions is evidenced an increase in globulins against albumin (3.1 g/dL albumin and $3.9 \mathrm{~g} / \mathrm{dL}$ globulin).

After the examinations results, the canine was submitted to castration, and moments earlier, a semen sample was collected for bacterial culture, morphological evaluation and PCR.

After castration, the testicles were sent for histopathology (Figure 2). Histological evaluation revealed an inflammatory infiltrate with a predominance of lymphocytes, interstitial, multifocal and moderate in the epididymis. In the testicular parenchyma was observed vacuolar degeneration of the germinal epithelium of seminiferous tubules, without testicular atrophy. In agreement with a study conducted by Gyuranecz (2011) on histological analysis of a canine with canine brucellosis that presented severe lymphohistiocytic inflammation.

Spermatozoa abnormalities become evident after 5 weeks of infection worsening at 8 weeks. The most commonly observed deformities are in immature spermatozoa, acrosome deformities, edema of intermediate pieces, retention of cytoplasmic droplets, the presence of coiled tails, head detachment and head-to-head agglutination (George et al., 1979; Grenne \& Charmichael, 2006). In the present study, the morphological evaluation of semen showed $25 \%$ of sperm abnormalities, among them, strongly folded tail, loose heads, coiled tails, head-heads (Figure 3).

The PCR, direct blood, blood enriched in tryptose broth, fresh semen, enriched semen, and enriched urine tests were positive for brucellosis in polymerase chain reaction (PCR), using specific primers for Brucella canisThese results show the sensitivity of the test, it collaborates as a diagnostic method, as well as allows the use of different types of biological materials.

The semen examination by PCR should be included as a diagnosis and prevention of canine brucellosis in natural mating and artificial insemination of dogs suitable for breeding (Kim et al., 2006; Keid et al., 2007a). In a study by Keid et al. (2009) reported 25 dogs that were negative in the microbiological culture and were positive for PCR in blood samples and of genital materials, reinforcing the sensitivity of the molecular examination and the importance as a diagnostic aid. In this case, the PCR was indispensable for the diagnosis of this disease, because with the negative bacterial culture, it would not be possible to confirm the disease only with the 


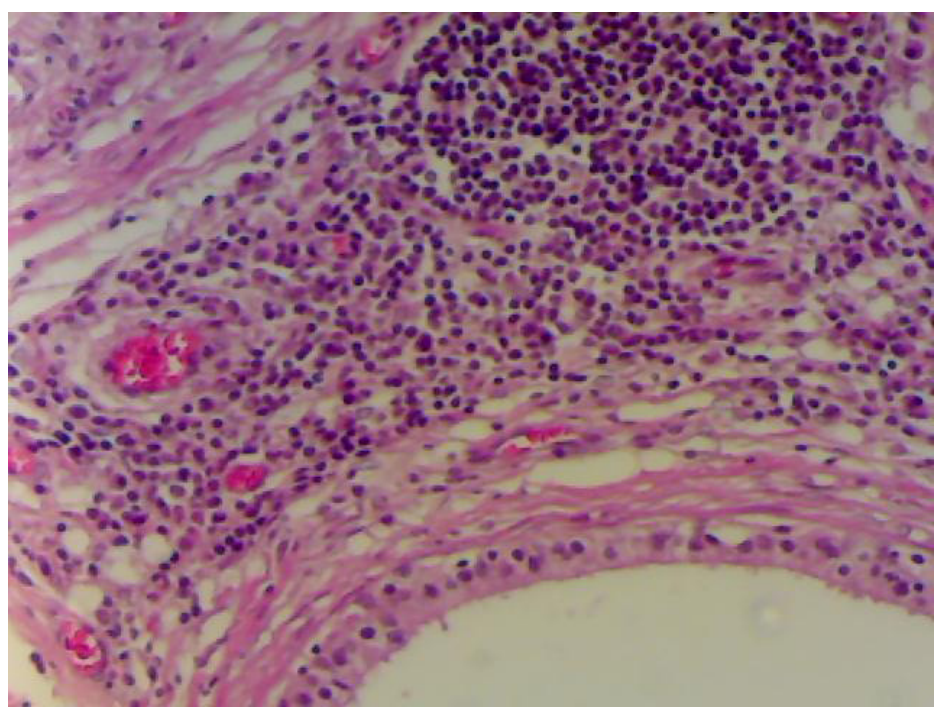

Figure 2. Epididymis micrograph: inflammatory infiltrate with interstitial lymphocytes predominance (HeE) $40 X$.

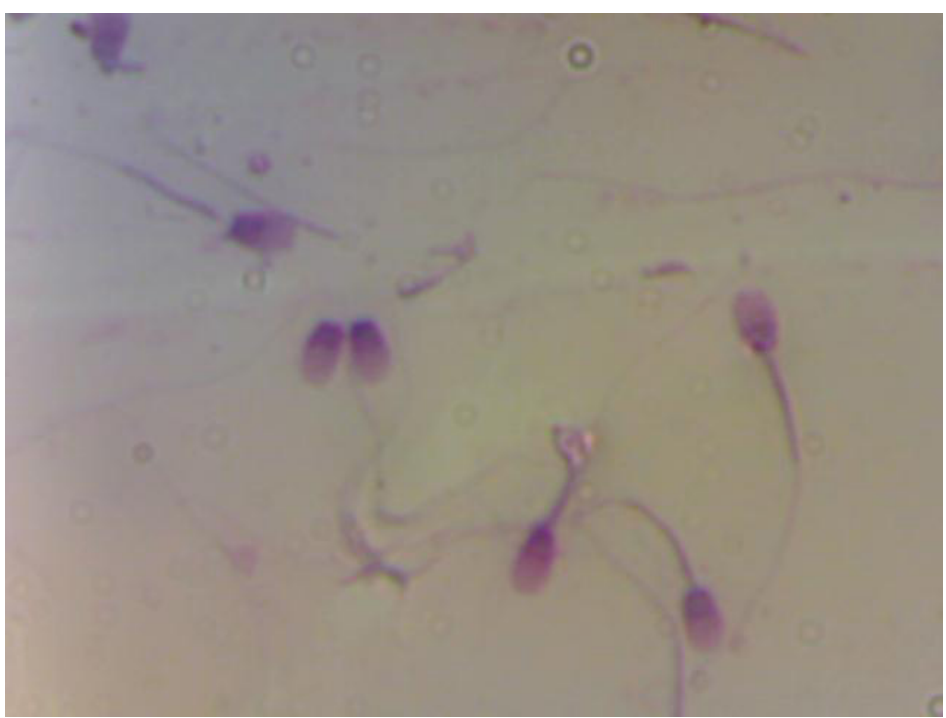

Figure 3. Morphological evaluation of semen.

serological examination, being evidenced the PCR test relevance to collaborate as a diagnostic tool of the Canine brucellosis.

The treatment is prolonged and the cure is difficult to achieve, especially in chronically infected males, since the prostate sequesters the organisms. Castration of affected males and administration of antibiotic therapy are indicated. The results obtained with success were the association of doxycycline with streptomycin (Shin \& Carmichael, 1999). This protocol was established in the present report canine, associated with isolation and control of the environment.

\section{Conclusions}

PCR is a fast and accurate method of diagnosing canine brucellosis and is very important for public health, for the disease eradication and control. It is less dangerous compared to the microbiological culture and the result is emitted within a short period, evidence that it can be recommended as an effective diagnostic method. It has been shown to be an excellent tool as a diagnostic implement for canine brucellosis, due to its sensitivity, speed of results and also 
to enable the testing of several types of individual materials, proving to be a very versatile and valuable test.

Little has been done in the face of reality in the country. This work underscores theimportance of this disease because it is a zoonosis and the public health risk is clear.

\section{References}

Alton, G. G., Jones, L. M., Angus, R. D., \& Verger, J. M. (1988). Techniques for the brucellosis laboratory. Paris: INRA.

Anderson, G. I., \& Binnington, A. G. (1983). Discospondylitis and orchitis associated with high Brucella titre in a dog. The Canadian Veterinary Journal. La Revue Veterinaire Canadienne, 24(8), 249-252. PMid:17422294.

Aras, Z., \& Uçan, U. S. (2010). Detection of Brucella canis from inguinal lymph nodes of naturally infected dogs by PCR. Theriogenology, 74(4), 658-662. http://dx.doi.org/10.1016/j.theriogenology.2010.03.023. PMid:20452003.

Bricker, B. J. (2002). PCR as a diagnostic tool for brucellosis. Veterinary Microbiology, 90(1-4), 435-446. http:// dx.doi.org/10.1016/S0378-1135(02)00228-6. PMid:12414163.

Carmichael, L. E., \& Grenne, C. E. (2006). Canine Brucellosis. In C. E. Greene (Ed.), Infectious dieses of the dog and cat (3th ed., chapter 40, pp. 369-381) Saint Louis: Elsevier Sanders.

Echeverri, C. A. G., Cotés, Z. T. R., \& Ángel, M. O. (2009). Brucella canis em Medellín (Colombia), um problema actual. Revista UDCA Actualidad \& Divulgação Científica, 12(1), 51-57.

Escobar, G. I., Boeri, E. J., Ayala, S. M., \& Lucero, N. E. (2010). The feasibility of using antigens prepared with rough Brucella strains for diagnosis of canine brucellosis. Revista Argentina de Microbiologia, 42(1), 35-40. PMid:20461292.

George, L. W., Duncan, J. R., \& Carmichael, L. E. (1979). Semen examination in dogs with canine brucellosis. American Journal of Veterinary Research, 40(11), 1589-1595. PMid:525878.

Gyuranecz, M., Szeredi, L., Rónai, Z., Dénes, B., Dencsö, L., Dán, A., Pálmai, N., Hauser, Z., Lami, E., Makrai, L., Erdélyi, K., \& Jánosi, S. (2011). Detection of Brucella canis - induced reproductive diseases in a kennel. Journal of Veterinary Diagnostic Investigation, 23(1), 143-147. http://dx.doi.org/10.1177/104063871102300127. PMid:21217047.

Hollett, R. B. (2006). Canine brucellosis: outbreaks and compliance. Theriogenology, 66(3), 575-587. http://dx.doi. org/10.1016/j.theriogenology.2006.04.011. PMid:16716382.

Keid, L. B., Soares, R. M., Morais, Z. M., Richtzenhain, L. J., \& Vasconcellos, S. A. (2004). Brucella spp. Isolation from dogs from comercial breeding kennels in São Paulo State, Brazil. Brazilian Journal of Microbiology, 35(1-2), 161-166. http://dx.doi.org/10.1590/S1517-83822004000100027.

Keid, L. B., Soares, R. M., Vasconcellos, S. A., Chiebao, D. P., Megid, J., Salgado, V. R., \& Richtzenhain, L. J. (2007a). A polymerase chain reaction for the detection of Brucella canis in semen of naturally infected dogs. Theriogenology, 67(7), 1203-1210. http://dx.doi.org/10.1016/j.theriogenology.2007.01.003. PMid:17343907.

Keid, L. B., Soares, R. M., Vasconcellos, S. A., Megid, J., Salgado, V. R., \& Richtzenhain, L. J. (2009). Comparison of agar gel immunodiffusion test, rapid slide agglutination test, microbiological culture and PCR for the diagnosis of canine brucellosis. Research in Veterinary Science, 86(1), 22-26. http://dx.doi.org/10.1016/j.rvsc.2008.05.012. PMid:18656213.

Keid, L. B., Soares, R. M., Vieira, N. R., Megid, J., Salgado, V. R., Vasconcellos, S. A., Costa, M., Gregori, F., \& Richtzenhain, L. J. (2007b). Diagnosis of canine brucellosis: comparison between serological and microbiological testes and a PCR based on primers to 16S-23S r DNA interspace. Veterinary Research Communications, 31(8), 951-965. http://dx.doi.org/10.1007/s11259-006-0109-6. PMid:17308888.

Kim, S., Lee, D. S., Suzuki, H., \& Watarai, M. (2006). Detection of Brucella canis and Leptospira interrogans in Canine Semen by Multiplex Nested PCR. The Journal of Veterinary Medical Science, 68(6), 615-618. http:// dx.doi.org/10.1292/jvms.68.615. PMid:16820720.

Ledbetter, E. C., Landry, M. P., Stokol, T., Kern, T. J., \& Messick, J. B. (2009). Brucella canis endophthalmitis in 3 dogs: clinical features, diagnosis, and treatment. Veterinary Ophthalmology, 12(3), 183-191. http://dx.doi. org/10.1111/j.1463-5224.2009.00690.x. PMid:19392878.

Mateu-de-Antonio, E. M., Martin, M., \& Casal, J. (1994). Comparison of serologic tests used in canine brucellosis diagnosis. Journal of Veterinary Diagnostic Investigation, 6(2), 257-259. http://dx.doi.org/10.1177/1040638794 00600220. PMid:8068761.

Megid, J., Mathias, L. A, \& A. Robles, C. (2010). Clinical manifestations of Brucellosis in domestic animals and humans. The Open Veterinary Science Journal, 4(1), 119-126. http://dx.doi.org/10.2174/1874318801004010119.

Minharro, S., Cottorello, A. C. P., Miranda, K. L., Stynen, A. P. R., Alves, T. M., \& Lage, A. P. (2005). Diagnóstico da brucelose canina: dificuldades e estratégias. Revista Brasileira de Reprodução Animal, 29, 167-173.

Noosud, J., Sirinarumitr, K., \& Sirinarumitr, T. (2009). Comparison of a Serological Method, a Bacteriological Method and16S rRNA Brucella canis PCR for Canine Brucellosis Diagnosis. Witthayasan Kasetsat Witthayasat, 43, 159-164.

Pappas, G., Akritidis, N., Bosilkovski, M., \& Tsianos, E. (2005). Brucellosis. The New England Journal of Medicine, 352(22), 2325-2336. http://dx.doi.org/10.1056/NEJMra050570. PMid:15930423. 
Shin, S., \& Carmichael, L. E. (1999). Canine Brucellosis caused by Brucella canis. In L. E. Carmichael (Ed.), Recent advances in canine infectious disease. New York: Internacional Veterinary Information Service.

Vieira, N. R. (2004). Desenvolvimento de uma reação em cadeia pela polimerase (PCR) para detecção de Brucella spp. Em amostras de sangue de cães naturalmente infectados (Dissertação de mestrado). Faculdade de Medicina Veterinária e Zootecnia da Universidade de São Paulo, São Paulo.

Wanke, M. M. (2004). Canine Brucellosis. Animal Reproduction Science, 82-83, 195-207. http://dx.doi.org/10.1016/j. anireprosci.2004.05.005. PMid:15271453. 